\title{
BIOGAS PRODUCTION POTENTIAL IN ANAEROBIC DIGESTION OF SWINE MANURE WITH DIFFERENT SOLID FRACTION CONCENTRATIONS AND TEMPERATURES
}

\author{
Adriano Adelson Costa ${ }^{1}$, Maira Oliveira Silva ${ }^{2}$, Marcos Eduardo Paron ${ }^{3}$, \\ Josirley de Fátima Corrêa Carvalho ${ }^{4}$, Jorge de Lucas Júnior ${ }^{5}$, Alex Luiz \\ Sagula $^{6}$, Aline Fernandes ${ }^{7}$, Max Ternero Cangani ${ }^{8}$, Sergio Santos Azevedo ${ }^{9}$ \\ and Francisco Rafael Martins Soto ${ }^{10}$
}

\begin{abstract}
This work aimed to evaluate the biogas production potential of swine manure (SM) under different temperatures through the use of experimental biodigesters (EB), investigating the physical, chemical and microbiological parameters of the process. The experiment consisted of three treatments a) with solid fraction separation (WSSF), b) without solid fraction separation (W-SSF) and c) solid fraction only (OSF). The assays were performed in triplicate and submitted to room temperature (RT) (13.36 to $23.71^{\circ} \mathrm{C}$ ) and to controlled temperature $\left(30.00^{\circ} \mathrm{C}\right)$, during 28 days. The average biogas production in the EB was $390.41 \mathrm{ml}$ (WSSF), $390.53 \mathrm{ml}$ (W-SSF) and $400.53 \mathrm{ml}$ (OSF), at RT and $393.00 \mathrm{ml}$ (WSSF), $393.00 \mathrm{ml}$ (W-SSF) and $390.67 \mathrm{ml}$ (OSF) at $30.00^{\circ} \mathrm{C}$. The results showed that significant differences occurred in the biogas production due to the different treatments and temperatures. The highest average reduction of parameters as a function of treatment and temperature was $53.22 \%$ for total solids in WSSF $\left(30^{\circ} \mathrm{C}\right), 10.73 \%$ for nitrogen in $W$-SSF (RT), $27.50 \%$ for phosphorus in the WSSF (TA), 63.55\% for the COD in the W-SSF (TA), 99,10\% for the total coliforms in the W-SSF (TA) and $99.59 \%$ for the thermotolerant coliforms in the WSSF $\left(30^{\circ} \mathrm{C}\right)$.
\end{abstract}

Keywords: Swine farming. Biodigesters. pH. Temperature. Methane gas. Coliforms.

\section{Introduction}

Swine farming is an important activity in the agribusiness (VIANCELLI et al., 2013). In the meat market it is responsible for the creation of jobs, acting as an incomestabilizing factor for thousands of families (FERNANDES et al., 2014; SUZUKI et al., 2014).

The world consumption of pork is in expansion, which leads to an increase in the demand for the production of this type of protein (CARVALHO; SOUZA; SOTO, 2015). As a consequence of this process, swine farming has incorporated technological innovations in their production systems which have allowed the rearing of herds in the intensive form in increasingly smaller areas (URBINATI; DUDA; OLIVEIRA, 2013). However, this scenario has led to an increase in the generation of swine manure (SM) which has an important polluting potential, and may cause environmental and sanitary imbalances if inappropriately managed (DUDA ;OLIVEIRA, 2011; MENG et. al., 2013).

One of the alternatives for the adequate treatment of the SM in the first

\footnotetext{
${ }^{1}$ E-mail: adrianocosta1405@hotmail.com

2E-mail: maira.oliveira.silva@gmail.com

33E-mail: marcoseparon@yahoo.com.br

${ }^{4}$ E-mail: josie.carvalho@hotmail.co.uk

${ }^{5}$ E-mail: jlucas@fcav.unesp.br

${ }^{6}$ E-mail: alexsagula@gmail.com

7E-mail: aline.nands@hotmail.com

${ }^{8}$ E-mail: max_tc@hotmail.com

${ }^{9}$ E-mail: sergio@vps.fmvz.usp.br

${ }^{10}$ E-mail: chicosoto34@gmail.com
}

Instituto Federal de Educação, Ciência e Tecnologia de São Paulo, Campus São Roque. Rodovia Prefeito Quintino de Lima, 2100, Paisagem Colonial - CEP 18.126-540- São Roque - SP. 


\section{REA - Revista de estudos ambientais (Online)} v.19, n. 1, p.6-17, jan./jun. 2017

stages is the anaerobic biodigestion (HALMEMAN et al., 2014; SANTOS; OLIVEIRA, 2011). It is a process decomposition of organic matter by different groups of microorganisms in the absence of free molecular oxygen which results in two main sub-products: biogas and biofertilizer (KLEINSTEUBER 2014; OLIVEIRA; DUDA; FERNANDES, 2014; SILVA et al., 2013; SUÁREZ et al, 2014). The first may be used as biofuel in the generation of electric and / thermal power and the second in the organic fertilization of the soil, thereby generating value-added products (GALBIATTI et al., 2010; RODRIGUEZ-VERDE et al., 2014).

The quantity of SM which is produced daily by the swine farming activity constitutes a source of biomass which may be used in a sustainable way for the generation of renewable energy with an important contribution for the agribusiness chains (KONRAD et. al., 2014; LIMA; MIRANDA, 2014; MÖNCH-TEGEDER; LEMMER; OECHSNER, 2014; XIE et al., 2011).

The anaerobic digestion process culminated with the development of biodigesters (AQUINO et al., 2014). There are several models of biodigesters, however the most common ones are the Indian, Chinese and Canadian, and each one has a peculiarity, but all with the same objective: they all create an environment with the absence of oxygen which promote the growth of the anaerobic bacteria, which will decompose the organic matter and produce biogas, and, in addition, these systems have structures to store the gas (SOUZA; MIRANDA, 2012; XAVIER; LUCAS JÚNIOR, 2010).

The treatment of the SM having as a protagonist the use of biodigesters has important environmental and health impacts (SUNADA et al., 2012). Their use contributes to the decrease of the surface water, soil and groundwater pollution, caused by the inadequate disposal of SM and also reduces the emission of greenhouse gases, mainly the methane gas (GARFí et al., 2012; MANNING; HADRICH, 2015). Furthermore, it reduces the sources of proliferation of disease-causing vectors (TIETZ; SOARES; SANTOS, 2013).

Taking into account this bioenergy and biofertilizer production potential and the mitigation of environmental and health impacts obtained by the treatment of MS by anaerobic biodigestion, it is important to carry out research that seeks to improve this technology by exploring the possibilities of greater gas production, as well as the improvement of the positive impacts on health and the environment.

This work aimed to evaluate the biogas production potential of SM containing different solid fraction concentrations subjected to anaerobic digestion in experimental biodigesters under ambient temperatures as well as $30^{\circ} \mathrm{C}$, investigating the physical, chemical and microbiological parameters of the process.

\section{Methodology}

This work was carried out in the experimental area of the Federal Institute of Education, Science and Technology of São Paulo, Brazil, São Roque campus (IFSP$S R Q$ ), in the period from 07 May - 03 June 2015, totaling 28 days. 18 experimental biodigesters (EB) were built having as biomass the SM which was acquired from a technified swine farm located in the municipality of Ibiúna- SP, Brazil.

Six treatments were carried out using a completely randomized design, in a 6X3X2 factorial scheme, with three replications each, being three of them submitted to room temperature $\left(13,36^{\circ} \mathrm{C}-23,71^{\circ} \mathrm{C}\right)(\mathrm{RT})$ and the others to $30{ }^{\circ} \mathrm{C}$ which were maintained in a digital oven of bacterial cultivation.

The EB which remained under RT and at $30^{\circ} \mathrm{C}$ (mesophilic temperature range) were filled as follows, a) with separation of the solid fraction (WSSF), b) without separation of the solid fraction (W-SSF) and c) only the solid fraction (OSF) (Figure 1). The swine manure used was composed of excrements, urine, sawing, water lost in the wash of the stalls and in the drinker of animals. In the experimental group the OSF solid materials decanted in the box were used. The WSSF group encompassed the supernatant liquid. And the W-SSF included the mixture of solid sedimentary with the supernatant. In order to obtain the SM WSSF, a $6,35 \mathrm{~mm}$ sieve was used, attached to a decanting box, referred to the solid gross fraction an the SM which passed through the sieve constituted the W-SSF. 


\section{REA - Revista de estudos ambientais (Online) v.19, n. 1, p.6-17, jan./jun. 2017}

Figure 1 - Schematic representation of the experiment

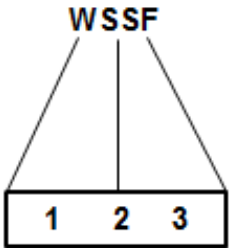

$\begin{array}{lll}1 & 2 & 3\end{array}$
RT

$30^{\circ} \mathrm{C}$

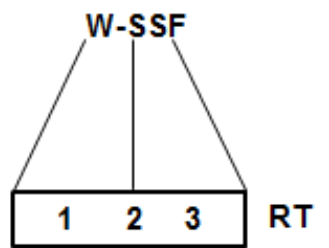

$\begin{array}{lll}1 & 2 & 3 \\ \end{array} 30^{\circ} \mathrm{C}$

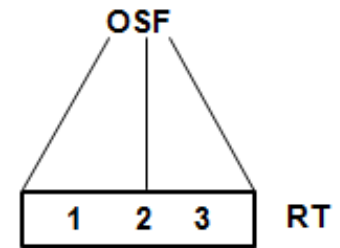

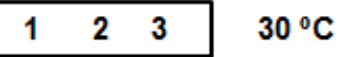

The EB were constructed from polyethylene bottles with a maximum volume of two liters and single supply (batch model). In these bottles was inserted a pipe with 60 $\mathrm{mm}$ of length and $20 \mathrm{~mm}$ diameter and polyvinyl chloride caps. A flexible plastic hose with $1.20 \mathrm{~m}$ length and $2 \mathrm{~mm}$ of diameter was connected at one side at this pipe and at the other one at a graduated plastic syringe with maximum volume of $60 \mathrm{~mL}$ (Figure 2).

Each EB received the volume of $1.630 \mathrm{~L}$ of $\mathrm{SM}$ in their different treatments and replications.

Figure 2 - Scheme of the experimental biodigester used in the work

Volume of SM in their different treatments $\mathrm{V}=1,630 \mathrm{~L}$

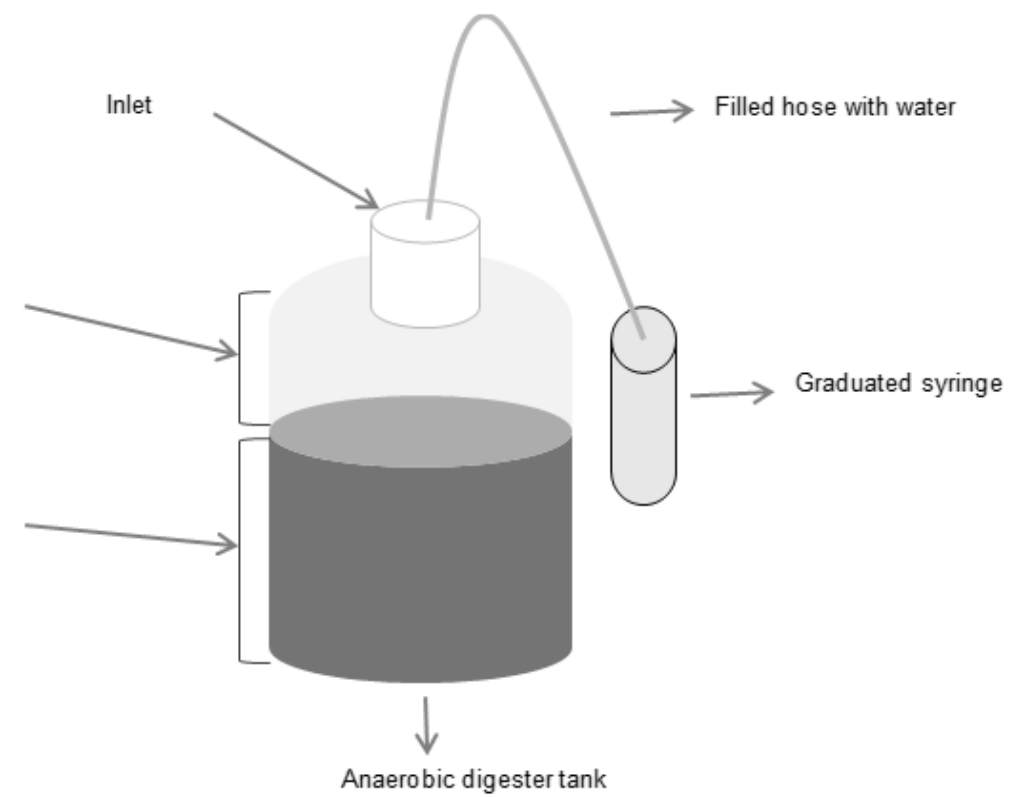

For the assessment of the biogas production in the different $E B$, the entire interior of the hose was filled with water. The water displacement and accumulation in the syringe indicates the biogas production in each EB (Figure 2).

The biogas production in the EB was measured daily throughout the 28-day period. For the EB which were maintained in RT, it was checked at pre-determined times during the 28 days in which the experiment was carried out.

For the determination of the $\mathrm{pH}$, Total Solids (TS), nitrogen, phosphorus, Chemical Oxygen Demand (COD), Total Coliforms (TC) and Thermotolerant Coliforms (TtC) a sample of $500 \mathrm{~mL}$ was collected in each EB at day zero and at the $28^{\text {th }}$ day and stored under refrigeration. These parameters have been analyzed according to the methodologies described in Table 1.

To compare the results from the different groups (WSSF, W-SSF and OSF) for each temperature (RT and $30^{\circ} \mathrm{C}$ ) and the experimental moments (days 0 and 28) the General Linear Model was used, with multiple comparisons with the Tukey's test (ZAR, 1999). The level of significance adopted in all the analysis was 0.05 , and the statistical package used was the SPSS for Windows 20.0 . 


\section{REA - Revista de estudos ambientais (Online) v.19, n. 1, p.6-17, jan./jun. 2017}

Table 1 - Parameters and methods used in this work

\begin{tabular}{l|l}
\hline Parameters & Method \\
\hline $\mathrm{pH}$ & $\begin{array}{l}\text { Reaction in calcium chloride method (Raij et al. 2001) } \\
\text { APHA (2000) }\end{array}$ \\
$\begin{array}{l}\text { Total Solids (TS) } \\
\text { Nitrogen and the phosphorus }\end{array}$ & Semi-micro Kjeldahl method (AOAC 1990) \\
$\begin{array}{l}\text { Chemical Oxygen Demand (COD) } \\
\text { Total Coliforms (TC) and } \\
\text { Thermotolerant Coliforms (TtC) }\end{array}$ & $\begin{array}{l}\text { Vanderzant technique, (VANDERZANT; SPLITTSTOESSER, 1992); } \\
\text { SILVA; JUNQUEIRA V. C. A.; SIVEIRA (2007) }\end{array}$ \\
\hline
\end{tabular}

\section{Results and discussion}

In Table 2 are presented the results concerning the average biogas production in the three treatments submitted to different temperatures during the 28 days in which the experiment was carried out.

The average RT during the period of the experiment was $18.54^{\circ} \mathrm{C}$, with a minimum of $13.36^{\circ} \mathrm{C}$ and maximum of $23.71^{\circ} \mathrm{C}$, which indicated favorable conditions for the growth of psychrophile microorganisms (KASHYAP; DADHICH; SHARMA, 2003; MASSÉ et al., 2008). It was observed that in the SFS EB maintained in this temperature condition, the average biogas production was $10 \mathrm{~mL}$ higher than that produced in the WSSF and W-SSF $E B$, and $W-S S F E B$ and the average biogas production in the WSSF and W-SSF EB are equal.

As for the EBs submitted to $30^{\circ} \mathrm{C}$, in which was established an optimal growth condition of mesophilic microorganisms, the average of the EB WSSF presented an increase on biogas production when compared to the EBs of the W-SSF and OSF treatments, which practically had the same performance (Table 2).

Table 2- Average biogas production $(\mathrm{mL})$ in the six treatments with experimental biodigesters submitted to different temperatures during 28 days

\begin{tabular}{|c|c|c|}
\hline Treatment & Room temperature $\left(13.36-23.71^{\circ} \mathrm{C}\right)$ & Temperature at $30.00^{\circ} \mathrm{C}$ \\
\hline WSSF & 390.41 & 393.00 \\
\hline W-SSF & 390.53 & 389.75 \\
\hline OSF & 400.53 & 390.67 \\
\hline
\end{tabular}

WSSF- with separation of the solid fraction; W-SSF- without separation of the solid fraction; OSF- only the solid fraction.

However significant differences $(p<0.05)$ in the average biogas production between the EB WSSF and OSF as well as between OSF and W-SSF in RT were detected. The comparison between the EBs submitted to $30^{\circ} \mathrm{C}$ showed no significant differences in the average biogas production $(p<0.05)$. Miranda et al. (2012) and Orrico Júnior, Orrico and Lucas Junior (2009a), also working with anaerobic biodigestion of SM, have obtained a biogas production with higher average values. However it must be taken into account that in the present study was not carried out the previous microbial biostabilization with activated iodine or other types of pre-treatments, as researched by Athanasoulia, Melidis and Aivasidis (2012) and Zhang et al. (2010), which can improve quality of the biomass, leading to the optimization of the process and an increase of the microbial activity, culminating in an greater biogas production. In future works, it is possible that with the previous establishment of an active anaerobic microbial flora, longer hydraulic detention time and agitation of the substrate, a greater biogas production produced by the same biomass forms originated from the SM 


\section{REA - Revista de estudos ambientais (Online)} v.19, n. 1, p.6-17, jan./jun. 2017

(WSSF, W-SSF and OSF) will happen. These alternatives may influence the general dynamics of the process of organic matter degradation by anaerobic routes (MOTTET et al., 2010).
In Table 3 are presented the $\mathrm{pH}$ behavior in the six treatments with $\mathrm{EB}$ submitted to RT and to $30^{\circ} \mathrm{C}$.

Table 3- Average $\mathrm{pH}$ in the six treatments with experimental biodigesters

\begin{tabular}{llclc}
\hline Treatment & \multicolumn{2}{l}{ Room temperature $\left(13.36^{\circ} \mathrm{C}-23.71^{\circ} \mathrm{C}\right)$} & \multicolumn{2}{l}{ Temperature at $\mathbf{3 0 . 0 0}^{\circ} \mathrm{C}$} \\
\hline & Day 0 & Day 28 & Day 0 & Day 28 \\
\hline WSSF & 8.04 & 7.26 & 8.04 & 7.44 \\
W-SSF & 7.12 & 5.81 & 7.12 & 6.86 \\
OSF & 7.26 & 5.34 & 7.26 & 5.45
\end{tabular}

WSSF- with separation of the solid fraction; W-SSF- without separation of the solid fraction; OSF- only solid fraction.

At day zero with EB maintained at $\mathrm{RT}$, the $\mathrm{pH}$ values oscillated around neutral values for the W-SSF and OSF treatment and around alkaline values for WSSF treatment; $\mathrm{pH}$ ranges that provides microorganisms growth (Table 3 ). On the $28^{\text {th }}$ day, there was a change of values, with the prevalence of acid $\mathrm{pH}$ in the EB W-SSF and OSF and neutrality in the EB WSSF (Table 3). Such results showed the influence of the $S M$ in its different forms on the microbial flora's dynamics, initially with affinity for $\mathrm{pH}$ values between neutrality and alkalinity, and at the end, having predominantly acidophilic microorganisms. It is worth pointed out that these average $\mathrm{pH}$ values are within the minimum and maximum variation ranges for the growth of the majority of the anaerobic microorganisms, which is between 4.0 and 9.0 (PEREIRA et al., 2009). It is evidenced, in this way that the alkalinity or the acidity is due to the interaction between the community of microorganisms and the substrate (HORIUCHI et al, 2002).

The EB submitted to $30^{\circ} \mathrm{C}$ present practically the same results that the EB maintained at RT, at day zero, , with neutral values in the EB W-SSF and OSF and alkaline values in the EB WSSF (Table 3). On the $28^{\text {th }}$ day the $\mathrm{pH}$ have changed only in the EB OSF becoming acid, while the others W-SSF and WSSF continued to having a neutral $\mathrm{pH}$. These results indicated that the temperature influenced these parameters and the established microbial flora that presents an optimum growth in $\mathrm{pH}$ in the neutrality range (that is greater metabolic activity). The $\mathrm{pH}$ reduction in both $\mathrm{EB}$ submitted to RT as well as to $30^{\circ} \mathrm{C}$ may be explained by the formation of acid compounds such as the volatile fatty acids (AQUINO; CHERNICHARO, 2005).

The statistical analysis of the $\mathrm{pH}$ at the different $E B$, at day zero and $28^{\text {th }}$, and RT and $30^{\circ} \mathrm{C}$, showed that there was significant difference $(p<0.05)$ at day zero for the treatments: WSSF (RT) and OSF (RT); WSSF (RT) and W-SSF (RT); WSSF $\left(30^{\circ} \mathrm{C}\right)$ and OSF $\left(30^{\circ} \mathrm{C}\right)$; WSSF $\left(30^{\circ} \mathrm{C}\right)$ and W-SSF $\left(30^{\circ} \mathrm{C}\right)$; OSF $\left(30^{\circ} \mathrm{C}\right)$ and $\mathrm{W}$-SSF $\left(30^{\circ} \mathrm{C}\right)$. The comparison between the days 0 and 28 showed that there were significant differences in all the treatments submitted to the two temperatures.

The average TS values in the six treatments with experimental biodigesters submitted to RT and to $30^{\circ} \mathrm{C}$ on days zero and $28^{\text {th }}$ are represented in Table 4.

It was observed that a greater reduction of TS $(43.54 \%)$ occurred in the $\mathrm{EB}$ WSSF, maintained at RT. In the EB W-SSF, there was little consumption of organic matter, a reduction of $17.21 \%$. For the EB with OSF, there was an increase of TS.

The results of the TS in the EB maintained at $30^{\circ} \mathrm{C}$ were similar to those of the EB submitted to RT, with a reduction of $53.22 \%$ of TS in the EB WSSF. In the EB with W-SSF, there was a lower reduction of $6.62 \%$. As for the EB OSF, the difference between the values on day zero and $28^{\text {th }}$ demonstrated lower performance compared to other treatments (table 4).

Those results indicated that the temperature did not influence the TS values. However, both the WSSF treatments presented significant reductions in the percentage of TS, which were superior to 


\section{REA - Revista de estudos ambientais (Online) v.19, n. 1, p.6-17, jan./jun. 2017}

those obtained by Vivan et al. (2010) that have treated SM combining anaerobic reactors with stabilization ponds. The EB WSSF did not achieve significant reductions in both temperatures; however this can be explained by the fact that this substrate without separation has a greater load of solids if compared to the WSSF substrate, taking more time for the degradation of this fraction of organic matter. This demonstrates that a greater hydraulic detention time or the quantity of the solid fraction may optimize the decomposition process (ORRICO JÚNIOR; ORRICO; LUCAS JUNIOR, 2009b).

Table 4- Average values of total solids (TS) (\%) in the six treatments with experimental biodigesters

\begin{tabular}{|c|c|c|c|c|}
\hline \multirow[t]{2}{*}{ Treatment } & \multicolumn{2}{|c|}{ Room temperature $\left(13.36^{\circ} \mathrm{C}-23.71^{\circ} \mathrm{C}\right)$} & \multicolumn{2}{|c|}{ Temperature at $30.00^{\circ} \mathrm{C}$} \\
\hline & Day 0 & Day 28 & Day 0 & Day 28 \\
\hline WSSF & 0.62 & 0.35 & 0.62 & 0.29 \\
\hline W-SSF & 1.51 & 1.25 & 1.51 & 1.41 \\
\hline OSF & 15.92 & 18.66 & 15.92 & 15.81 \\
\hline
\end{tabular}

WSSF- with separation of the solid fraction; W-SSF- without separation of the solid fraction; OSF- only solid fraction.

The total solids parameter at the different EB, day zero and $28^{\text {th }}$, RT and at $30^{\circ} \mathrm{C}$, presented significant difference $(p<0.05)$ at day o for the treatments: WSSF (RT) and OSF (RT); OSF (RT) and W-SSF (RT); WSSF $\left(30^{\circ} \mathrm{C}\right)$ and OSF $\left(30^{\circ} \mathrm{C}\right)$; OSF $\left(30^{\circ} \mathrm{C}\right)$ and $\mathrm{W}-\mathrm{SSF}\left(30^{\circ} \mathrm{C}\right)$. The comparisons between the days 0 and 28 showed significant differences in the treatment OSF submitted to RT.

In table 5 are presented the average results of nitrogen (TKN) and phosphorus in the six treatments with EB submitted to RT and to $30^{\circ} \mathrm{C}$ on days zero and $28^{\text {th }}$.

Table 5- Average results of nitrogen $(N)$ and phosphorus $(P)$ expressed in $\mathrm{mg} / \mathrm{L}$ in the six treatments (Treat) with anaerobic experimental biodigesters

\begin{tabular}{|c|c|c|c|c|c|c|c|c|}
\hline \multirow{3}{*}{ Treat } & \multirow{2}{*}{\multicolumn{4}{|c|}{$\begin{array}{l}\text { Room temperature }\left(13.36^{\circ} \mathrm{C}-23.71^{\circ} \mathrm{C}\right) \\
\mathrm{N}\end{array}$}} & \multicolumn{4}{|c|}{ Temperature at $30.00^{\circ} \mathrm{C}$} \\
\hline & & & & & $\mathbf{N}$ & & $\mathbf{P}$ & \\
\hline & Day 0 & Day 28 & Day 0 & Day 28 & Day 0 & Day 28 & Day 0 & Day 28 \\
\hline WSSF & 716.80 & 692.53 & 6978.15 & 5058.51 & 716.80 & 703.73 & 6978.15 & 6499.81 \\
\hline WSSF & 1495.20 & 1334.67 & 6364.22 & 7050.97 & 1495.20 & 1512.00 & 6364.22 & 7008.29 \\
\hline OSF & 1580.78 & 209.24 & 29886.76 & 15736.54 & 1580.78 & 220.41 & 29886.76 & 16445.40 \\
\hline
\end{tabular}

WSSF- with separation of the solid fraction; W-SSF- without separation of the solid fraction; OSF- only solid fraction

The average nitrogen results in the EB WSSF submitted to RT on day zero were 52.05 and $54.65 \%$, inferior to the W-SSF and OSF respectively (Table 5 ). This fact may be explained due to the lower concentration of organic matter in the EB-WSSF. This result assumes an environmental importance in the treatment of the SM in its initial stages. The retention of gross organic matter and nitrogen in the static screen allows these wastes to be treated with the use of other systems, for example, aerobic ponds, as investigated by Araújo et al. (2012). On the $28^{\text {th }}$ day, the reduction of nitrogen in the EB WSSF and WSSF was small: 3.38 and $10.73 \%$, respectively, indicating that the anaerobic biodigestion was not very efficient in the nitrogen removal. However in the EB OSF the reduction of this element was of $86.76 \%$. Ramires and Oliveira (2014) using a 


\section{REA - Revista de estudos ambientais (Online)} v.19, n. 1, p.6-17, jan./jun. 2017

UASB reactor in the treatment of wastewater obtained a total reduction of $69 \%$ of the nitrogen load.

In relation to the phosphorus, the values on day zero in the EB WSSF and WSSF were similar; indicating that the different forms of separation to which the SM was submitted did not contribute to reduce this chemical element. However, the EB submitted to the OSF treatment presented high phosphorus reduction values when compared to the other treatments: $76.65 \%$ and of $78.71 \%$ superior to the WSSF and WSSF, respectively. On the $28^{\text {th }}$ day, there was a reduction of $47.35 \%$ in the EB OSF and of $27.50 \%$ in the EB WSSF; however, in the EB W-SSF there was an increase of phosphorus in $9.73 \%$. Campos et al. (2006) in a laboratorial experiment with anaerobic reactors fed with SM also obtained variations in the average concentrations of phosphorus between the beginning and the end the experiment.

The results of nitrogen in the $E B$ maintained at $30^{\circ} \mathrm{C}$ had smaller reductions when compared to the EB submitted to RT, $86.1 \%$ for the EB OSF, $1.8 \%$ for the EB WSSF and an increase of $1.1 \%$ in the EB WSSF, probably due to the formation of nitrogen compounds by the microorganisms, such as nitrate and ammonia and to the adherence of these elements to the cytoplasm of the cells of the bacteria which are present in the formed iodine (SOUZA, 2012). Vivan et al. (2010) in an investigation with anaerobic biodigestion using swine manure also obtained an increase of the ammonium nitrogen.

For the phosphorus, the removal on the $28^{\text {th }}$ day, in the EB OSF was of $44.97 \%$ and in the EB WSSF was of $6.85 \%$, values inferior to those obtained in these same treatments submitted to RT, evidencing that the temperature of $30^{\circ} \mathrm{C}$ negatively influenced the removal of this element. In the EB: W-SSF, as occurred in the EB at RT, there was an increase of $9.19 \%$.

The nitrogen at the different EB, day zero and $28^{\text {th }}$, at RT and $30^{\circ} \mathrm{C}$, presented significant difference $(p<0.05)$ at day 0 for the treatments: WSSF (RT) and OSF (RT); WSSF (RT) and W-SSF (RT); OSF (RT) and W-SSF (RT); WSSF $\left(30^{\circ} \mathrm{C}\right)$ and OSF $\left(30^{\circ} \mathrm{C}\right)$; WSSF $\left(30^{\circ} \mathrm{C}\right)$ and W-SSF $\left(30^{\circ} \mathrm{C}\right)$; OSF $\left(30^{\circ} \mathrm{C}\right)$ and W-SSF $\left(30^{\circ} \mathrm{C}\right)$. The comparison between the days 0 and 28 showed significant differences only for the OSF treatment in both temperatures.

The phosphorus at the different EB, day zero and $28^{\text {th }}, \mathrm{RT}$ and at $30^{\circ} \mathrm{C}$, presented significant difference $(p<0.05)$ at day 0 for the treatments: WSSF (RT) and OSF (RT); OSF (RT) and W-SSF (RT); WSSF $\left(30^{\circ} \mathrm{C}\right)$ and OSF $\left(30^{\circ} \mathrm{C}\right)$; OSF $\left(30^{\circ} \mathrm{C}\right)$ and W-SSF $\left(30^{\circ} \mathrm{C}\right)$. The comparison between the days 0 and 28 showed significant differences in the OSF treatment submitted to both temperatures.

In table 6 are presented the average COD results in the four treatments with $E B$ submitted to RT and to $30^{\circ} \mathrm{C}$ on days zero and $28^{\text {th }}$.

Table 6- Average results of chemical oxygen demand (COD) (mg/L) in the four treatments (Treat) with experimental biodigesters submitted to room temperature and to $30^{\circ} \mathrm{C}$ on days zero and $28^{\text {th }}$

Treat

Room temperature $\left(13.00\right.$ to $\left.23.71^{\circ} \mathrm{C}\right)$

Temperature at $30.00^{\circ} \mathrm{C}$

\begin{tabular}{lllll}
\cline { 2 - 5 } WSSF & Day 0 & Day 28 & Day 0 & Day 28 \\
\cline { 2 - 5 } W-SSF & $5.675,00$ & $4.333,33$ & $5.675,00$ & $3.200,00$ \\
& $38.187,50$ & $13.916,67$ & $38.187,50$ & $18.733,33$ \\
\hline
\end{tabular}

WSSF- with separation of the solid fraction; W-SSF- without separation of the solid fraction.

It was observed that in the $\mathrm{EB}$ WSSF, both at RT and at $30^{\circ} \mathrm{C}$, the COD was significantly lower on day zero, when compared to the EB W-SSF (Table 6). Such result reinforces the importance of separating the gross solid fraction. The COD reduction efficiency in the anaerobic biodigestion stage, was of $23.64 \%$ in the EB WSSF and $63.55 \%$ in the EB W-SSF, respectively on the $28^{\text {th }}$ day at RT. Although the reduction of COD have been higher in BE W-SSF, the values obtained in BE WSSF are environmentally more favorable, because its potential of impact is smaller. Duda and Oliveira (2009a) with SM wastewater treatment in batched reactors obtained a COD reduction from 52 to $86 \%$. Rodrigues et al. (2010), in a work with swine farming wastewater using a 


\section{REA - Revista de estudos ambientais (Online) v.19, n. 1, p.6-17, jan./jun. 2017}

decanting system and a UASB reactor, obtained a total COD removal of $93 \%$ in 282 days of experiment. These studies confirm the perspective that a longer hydraulic detention time and the combination with other systems, could lead to greater effluent treatment efficiency.

In the EB submitted to $30^{\circ} \mathrm{C}$, the COD reduction was of $43.61 \%$ in the EB WSSF, a better result than that found when this EB was maintained at RT, specifically indicating, that the temperature may contributes to reduce COD. The COD reduction for the EB W-SSF was of $50.94 \%$, also lower than the EB W-SSF at RT. It is relevant to observe that the COD reduction by the anaerobic biodigestion process is linked to the formation of biogas that in turns is formed from the removal of the equivalent electrons which are the components that cause the COD (AQUINO et al., 2007).

In Table 7, are presented the results obtained in relation to the analysis of the TC and $\mathrm{TtC}$ in the six EB maintained at RT and at $30^{\circ} \mathrm{C}$ on days zero and $28^{\text {th }}$.

Table 7 - Average results of Total Coliforms (TC) and Thermotolerant Coliforms (TtC) (UFC $1 / \mathrm{mL}$ ) in the six treatments (Treat) with experimental biodigesters

\begin{tabular}{|c|c|c|c|c|c|c|c|c|}
\hline \multirow{3}{*}{ Treat } & \multicolumn{4}{|c|}{ Room temperature $\left(13.36\right.$ to $\left.23.71^{\circ} \mathrm{C}\right)$} & \multicolumn{4}{|c|}{ Temperature at $30.00^{\circ} \mathrm{C}$} \\
\hline & \multicolumn{2}{|l|}{ TC } & \multicolumn{2}{|l|}{ TtC } & \multicolumn{2}{|l|}{ TC } & \multicolumn{2}{|l|}{$\mathrm{TtC}$} \\
\hline & Day 0 & Day 28 & Day 0 & Day 28 & Day 0 & Day 28 & Day 0 & Day 28 \\
\hline WSSF & 240 & 12.66 & 240 & 2.76 & 240 & 3.60 & 240 & 0.98 \\
\hline W-SSF & 240 & 2.16 & 240 & 1.64 & 240 & 3.50 & 240 & 1.83 \\
\hline \multicolumn{9}{|l|}{ OSF } \\
\hline & 240 & 2.46 & 240 & 1.36 & 240 & 3.13 & 240 & 1.86 \\
\hline
\end{tabular}

1-Colony Forming Units, WSSF-with separation of the solid fraction; W-SSF- without separation of the solid fraction; OSF- only solid fraction.

In the six EB submitted to the two temperatures, the values of $\mathrm{TC}$ and $\mathrm{TtC}$, on day zero were elevated and equal to 240 UFC/mL. However, on the $28^{\text {th }}$ day, the anaerobic biodigestion showed to be efficient in the reduction of $\mathrm{TC}$ and $\mathrm{TtC}$ (Table 7 ), with significant statistical difference $(p<0.001)$ when compared results at day zero to the $28^{\text {th }}$ in all the EB. In the EB maintained at RT the average removal of $\mathrm{TC}$ and $\mathrm{TtC}$ was of $97.6 \%$ and $99.2 \%$ respectively, with the best result for TC in the W-SSF treatment and for $\mathrm{TtC}$ in the EB with OSF (Table 7). In the EB submitted to $30^{\circ} \mathrm{C}$, the average removal of TC and TtC was of $98.6 \%$ and $99.4 \%$ respectively, with the best result for $\mathrm{TC}$ in the EB with the OSF treatment and for $\mathrm{TtC}$ in the EB WSSF (Table 7). Duda and Oliveira (2009b) in a research with batched reactors fed with SM have obtained reduction values of $98.88 \%$ of TC and of $96.87 \%$ of $\mathrm{TtC}$, similar results to those found in the present work.

This elevated capacity of reduce the TtC and TC present in the SM due to the wide temperature variation is of great importance for the environment and health, and elects the anaerobic biodigestion as one of the protagonists in the satisfactory treatment of DS, and opens for the possibility of generation of sub-products of added value and with the capacity of mitigating impacts to the environment and to public health (ORRICO JUNIOR et al., 2012).

In relation to the statistical analysis for the TC parameter between the different $\mathrm{EB}$, day zero and $28^{\text {th }}$, at RT and at $30^{\circ} \mathrm{C}$, there was no difference for the treatments. For the TtC there was a difference $(p<0.05)$ for the WSSF and W-SSF treatment submitted to a temperature of $30^{\circ} \mathrm{C}$. The comparison between the days 0 and $28^{\text {th }}$ showed that there were significant differences in all the treatments submitted to the two temperatures.

\section{Conclusions}

The different ways of preparing swine manure and the temperatures at which this manure was subjected to anaerobic digestion 


\section{REA - Revista de estudos ambientais (Online) v.19, n. 1, p.6-17, jan./jun. 2017}

significantly influenced the biogas production in the experimental biodigesters, as well as the total solids, nitrogen and phosphorus removal efficiency and the $\mathrm{pH}$ value. The experimental group OSF subjected to ambient temperature and the WSSF subjected to $30^{\circ} \mathrm{C}$ obtained better performance in the production of biogas. Anaerobic digestion was also able to significantly reduce the total and thermotolerant coliforms and COD, showing the importance of this process from the point of view of health and environment, which allows the safe use of the effluent. To improve the process it is suggested to stabilize and agitate the substrate in order to facilitate the degradation of the organic matter and optimize the biogas production.

\section{Potencial de produção de biogás na digestão anaeróbia de dejetos suínos com diferentes concentrações de fração sólida e temperaturas}

Resumo: Este trabalho teve como objetivo avaliar o potencial de produção de biogás dos dejetos suínos (DS) sob diferentes temperaturas através do uso de biodigestores experimentais (BE), investigando-se os parâmetros físico-químicos e microbiológicos do processo. O experimento foi constituído de três tratamentos: a) com separação da fração sólida (CSFS), b) sem separação da fração sólida (SSFS) e c) somente fração sólida (SFS). Os ensaios foram realizados em triplicatas e submetidos à temperatura ambiente (13,36 a $\left.23,71^{\circ} \mathrm{C}\right)(T A)$ e à temperatura controlada $\left(30^{\circ} \mathrm{C}\right)$, durante 28 dias. A produção média de biogás nos $B E$ foi de $390,41 \mathrm{ml}$ (CSFS), 390,53 ml (SSFS) e 400,53 ml (SFS), em TA e 393,00 ml (CSFS), 393,00 ml (SSFS) e $390,67 \mathrm{ml}$ (SFS) a $30^{\circ} \mathrm{C}$. Os resultados mostraram que ocorreram diferenças significativas na produção de biogás devido aos diferentes tratamentos e temperaturas. A maior redução média dos parâmetros em função do tratamento e da temperatura foi de $53,22 \%$ para os sólidos totais no CSFS $\left(30^{\circ} \mathrm{C}\right), 10,73 \%$ para o nitrogênio no SSFS (TA), 27,50\% para o fósforo no CSFS (TA), de 63,55\% para a DQO no SSFS (TA), de $99,1 \%$ para os coliformes totais no SSFS (TA) e de $99,59 \%$ para os coliformes termotolerantes no CSFS $\left(30^{\circ} \mathrm{C}\right)$.

Palavras-chave: Suinocultura. Biodigestor. pH. Temperatura. Gás metano. Coliformes.

\section{References}

APHA. AWWA. WPCF. Standart methods for the examination of water and wastewater. 20th ed. Washington: American Public Health Association, 2000 .

AQUINO, S. F.; CHERNICHARO, C. A. L. Acúmulo de ácidos graxos voláteis (AGVs) em reatores anaeróbios sob estresse: causas e estratégias de controle. Engenharia Sanitária e Ambiental, v. 10, n. 2, p. 152-161, 2005.

AQUINO, S. F.; CHERNICHARO, C. A. L.; FORESTI, E.; SANTOS, M. L. F.; MONTEGGIA, L. O.; Metodologias para determinação da atividade metanogênica específica (AME) em lodos anaeróbios. Engenharia Sanitária e Ambiental, v. 12, n. 2, p. 192-201, 2007

AQUINO, G. T.; BRONDANI, F. M. M.; SOUZA, R. A. A.; GERON, V. L. M. G. O uso do biogás no âmbito rural como proposta de desenvolvimento sustentável. Revista Científica FAEMA, v. 5, n. 1, p. $140-149,2014$

ARAÚJO, I. S.; OLIVEIRA, J. L. R.; ALVES, R. G. C. M. BELLE FILHO, P.; COSTA, R. H. R. Avaliação de Sistema de tratamento de dejetos de suínos instalado no estado de Santa Catarina. Revista Barasileira de Engenharia Agrícola e Ambiental, v.16, n.7, p.745-753, 2012.

AOAC - ASSOCIATION OF OFFICIAL ANALYTICAL CHEMISTS -. Official methods of analysis. 15 ed. Washington: D.C., 1990

ATHANASOULIA, E.; MELIDIS, P.; AIVASIDIS, A Optimization of biogas production from waste activated sludge through serial digestion. Renewable Energy, v. 47, p. 147-151, 2012.

CAMPOS, C. M. M.; CARMO, F. R.; BOLTELHO, C. G.; COSTA, C. C. Desenvolvimento e operação de reator anaeróbio de manta de lodo (UASB) no tratamento dos efluentes da suinocultura em escala laboratorial. Ciência e Agrotecnologia, v. 30 , n. 1, p. 140-147, 2006.

CARVALHO, B. V.; SOUZA, A. P. M.; SOTO, F. R. M. Avaliação de sistemas de gestão ambiental em granjas de suínos. Revista Ambiente e Água, v. 10, n. 1, p. 164-171, 2015.

DUDA, R. M.; OLIVEIRA, R. A. Reatores anaeróbios operados em batelada sequencial, seguidos de lagoas de polimento, para o tratamento de águas residuárias de suinocultura. Parte I: produção de metano e remoção de DQO 


\section{REA - Revista de estudos ambientais (Online) v.19, n. 1, p.6-17, jan./jun. 2017}

e de sólidos suspensos. Engenharia Agrícola, v. 29 , n. 1, p. 122-134, 2009a.

DUDA, R. M.; OLIVEIRA, R. A. Reatores anaeróbios operados em batelada sequencial seguidos de lagoas de polimento para o tratamento de águas residuárias de suinocultura. Parte II: remoção de nutrientes e coliformes. Engenharia Agrícola, v. 29, n. 1, p. 135-147, 2009b.

DUDA, R. M. OLIVEIRA, R. A. Tratamento de águas residuárias de suinocultura em reator UASB e filtro anaeróbico em série seguidos de um filtro biológico percolador. Engenharia Sanitária e Ambiental, v. 16, n. 1, p. 91-100, 2011.

FERNANDES, D. M.; COSTANZI, R. N.; FEIDEN, A.; SOUZA, S. N. M.; KITAMURA, D. S. Processo de biodigestão anaeróbica em uma granja de suínos. Ambiência Guarapuava, v. 10, n. 3, p. 741-754, 2014

GALBIATTI, J. A. CARAMELO' A. D.; SILVA, F. G.; GERARDI, E. A. B.; CHICONATO' D. A. Estudo qualiquantitativo do biogás produzido por substratos em biodigestores tipo batelada. Revista Brasileira de Engenharia Agrícola e Ambiental, v. 14, n. 4, p. 432-437, 2010.

GARFÍ, M.; FERRER-MARTÍ, L.; VELO, E.; FERRER, I. Evaluating benefits of low-cost household digesters for rural Andean communities. Renewable and Sustainable Energy Reviews, v. 16, n. 1, p. 575-581, 2012.

HALMEMAN, M. C. R.; STACHISSINI, M.G.; DAMACENO, F. M.; GABRIEL FILHO, L. R. A.; CREMASCO, C. P.; PUTTI, F. F. The deployment of biodigester systems in rural properties. Brazilian Journal of Biosystems Engineering, v. 8, n. 4 , p. $351-360,2014$

HORIUCHI, J.I. I. SHIMIZU, T.; TADA, K.; KANNO, T.; KOBAYASHI, M. Selective production of organic acids in anaerobic acid reactor by $\mathrm{pH}$ control. Bioresource Technology, v. 82 , n. 3, p. 209-213, 2002

KASHYAP, D. R.; DADHICH, K. S.; SHARMA, S. K. Biomethanation under psychrophilic conditions: a review. Bioresource technology, v. 87 , n. 2, p. 147-153, 2003

KLEINSTEUBER, S. Special Issue on "Microbial Ecology of Anaerobic Digestion". Bioengineering, v. 1, p. 111-112, 2014.

KONRAD, O.; KOSH, F. F.; LUMI, M.; TONETTO, J. F.; BEZAMA, A. Potential of biogas production from swine manure supplemented with glycerine waste. Engenharia Agrícola, v. 34, n. 5, p. 844853, 2014.

LIMA, D. F. S.; MIRANDA, G. J. Economic and financial viability analysis of the use of biogas to produce electricity. Custos e Agronegocio, v. 10, n. 3, p. 83-99, 2014

MANNING, D. T.; HADRICH, J. C. An evaluation of the social and private efficiency of adoption: Anaerobic digesters and greenhouse gas mitigation. Journal of environmental management, v. 154, p. 70-77, 2015.

MASSÉ, D. I.; MASSE, L. HINCE, J. F.; POMAR, C. Psychrophilic anaerobic digestion biotechnology for swine mortality disposal. Bioresource technology, v. 99, n. 15, p. $7307-$ 7311, 2008

MENG, J.; WANG, L. LIU, X. WU, J.; BROOKES, P. C; XU, J. Physicochemical properties of biochar produced from aerobically composted swine manure and its potential use as an environmental amendment. Bioresource Technology, v. 142, p. 641-646, 2013

MIRANDA, A. P.; LUCAS JÚNIOR, J.; THOMAZ, M. C.; PEREIRA, G. T.; FUKAYAMA, E. H. Anaerobic biodigestion of pigs feces in the initial, growing and finishing stages fed with diets formulated with corn or sorghum. Engenharia Agrícola, v. 32, n. 1, p. 47-56, 2012.

MÖNCH-TEGEDER, M.; LEMMER, A.; OECHSNER, $H$. Enhancement of methane production with horse manure supplement and pretreatment in a full-scale biogas process. Energy, v. 73, p. 523-530, 2014.

MOTTET, A.; FRANÇOIS, E.; LATRILLE, E.; STEYER, J. P.; DÉLÉRIS, S.; VEDRENNE, F.; CARRĖR, $H$. Estimating anaerobic biodegradability indicators for waste activated sludge. Chemical Engineering Journal, v. 160, n. 2, p. 488-496, 2010.

OLIVEIRA, R. A.; DUDA, R. M.; FERNANDES, G. F. R. Reator anaeróbio compartimentado para o tratamento de águas residuárias de suinocultura. Engenharia Sanitária e Ambiental, v. 19, n. 4, p. 383-391, 2014

ORRICO JUNIOR, M. A. P.; ORRICO, A. C. A.; LUCAS JUNIOR, J. Potencial de produção de biogás remanescente nos efluentes de biodigestores abastecidos com dejetos de suínos, com e sem separação da fração sólida, e conduzida sob diferentes tempos de retenção hidráulica. Engenharia Agrícola, v. 29, n. 4, p. 679-686, 2009a.

ORRICO JUNIOR, M. A. P.; ORRICO, A. C. A.; LUCAS JUNIOR, J. Biodigestão anaeróbia de dejetos de suínos com e sem separação da fração sólida em diferentes tempos de retenção hidráulica. Engenharia Agrícola, v. 29, n. 3, p. 474-482, 2009b.

ORRICO JUNIOR, M. A. P.; ORRICO, A. C. A.; LUCAS JUNIOR, J.; SAMPAIO, A. A. M.; 


\section{REA - Revista de estudos ambientais (Online) v.19, n. 1, p.6-17, jan./jun. 2017}

FERNANDES, A. R. M.; OLIVEIRA, E. A.. Biodigestão anaeróbia dos dejetos da bovinocultura de corte: influência do período, do genótipo e da dieta. Revista Brasileira de Zootecnia, v. 41, n. 6, p. 1533-1538, 2012

PEREIRA, E. L.; CAMPOS, C. M. M.; MONTERANI, F.; NETO, A. M. Efeitos do pH, acidez e alcalinidade na microbiota de um reator anaeróbico de manta de lodo (UASB) tratando efluentes de suinocultura. Revista Ambiente e Água, v. 4, n.3, p. 157-168, 2009.

RAIJ, B. V.; ANDRADE, J.C.; CANTARELA, H.; QUAGGIO, J. A. Análise Química para Avaliação da Fertilidade de Solos Tropicais. Campinas: Instituto Agronômico, 2001.

RAMIRES, R. D.; OLIVEIRA, R. A. COD, TSS, nutrients and coliforms removals in UASB reactors in two stages treating swine wastewater. Engenharia Agrícola v. 34, n. 6, p. 1256-1269, 2014.

RODRIGUES, L. S.; SILVA, I. J.; ZOCRATO, D. N. P.; PAPA, D, N.; SPERLING, M. V.; OLIVEIRA, $P$. R. Avaliação de desempenho de reator UASB no tratamento de águas residuárias de suinocultura. Revista Brasileira de Engenharia Agrícola e ambiental, v. 14, n. 1, p. 94100, 2010.

RODRIGUEZ-VERDE, I.; REGUEIRO, L.; CARBALLA, M.; HOSPIDO, A.; LEMA, J. M. Assessing anaerobic co-digestion of pig manure with agroindustrial wastes: The link between environmental impacts and operational parameters. Science of The Total Environment, v. 497, p. 475-483, 2014.

SANTOS, A. C.; OLIVEIRA, R. A. Tratamento de águas residuárias de suinocultura em reatores anaeróbios horizontais seguidos de reator aeróbio em batelada sequencial. Engenharia Agrícola, v. 31 , n. 4 , p. $781-794,2011$

SILVA, N.; JUNQUEIRA V. C. A.; SIVEIRA, N. F. A. Manual de métodos de análises microbiológicas de alimentos. 3 ed. São Paulo: Livraria Varela, 2007, p. 119-129.

SILVA, C. O.; CESAR, V. R. S.; SANTOS, M. B.; SANTOS, A. S. Biodigestão anaeróbia com substrato formado pela combinação de esterco ovinocaprino, manipueira e biofertilizante. Revista Ibero-Americana de Ciências Ambientais, v. 4, n. 1, p. 88-103, 2013.

SOUZA, M. M. Estudo da inclusão de compartimentos em modelos de biodigestores modelo canadense. 2012. 117p. Dissertação (Mestrado em Engenharia de Processos). Universidade Federal de Santa Maria, Santa Maria (RS). 2012.
SOUZA, M. R. N.; MIRANDA, A. C. Protótipo de biodigestor: inserção da temática ambiental na escola. VIII Fórum Ambiental da Alta Paulista, v. 8, n. 6 , p. 48-59, 2012.

SUÁREZ, A. G. NIELSEN, K.; KÖHLER, S.; MORENCIO, D. O.; REYES, I. P. Enhancement of anaerobic digestion of microcrystalline cellulose (MCC) using natural micronutrient sources. Brazilian Journal of Chemical Engineering, v. 31, n. 2, p. 393-401, 2014

SUNADA, N. da S.; ORRICO, A. C. A.; ORRICO JÚNIOR, M. A. P.; VARGAR JÚNIOR, F. M.; GARCIA, R. G.; FERNADES, A. R. M. Potential of biogas and methane production from anaerobic digestion of poultry slaughterhouse effluent. Revista Brasileira de Zootecnia, v. 41, n. 11, p. 2379-2383, 2012.

SUZUKI, A. B. P.; FERNANDES, D. M.; FARIA, R. A. P.; SOUZA, S. M. N. Produção de biogás em escala real em unidade demonstrativa - Unidade Granja Colombari. Ambiência Guarapuava, v. 10, n. 1, p. 13-20, 2014.

TIETZ, C. M.; SOARES, P. R. H.; SANTOS, K. G. S.. Produção de energia pela biodigestão anaeróbica de efluentes: o caso da bovinocultura. Acta Iguazu, v. 2, n. 3, p. 15-29, 2013.

URBINATI, E.; DUDA, R. M.; OLIVEIRA, R. A. Performance of UASB reactors in two stages under different HRT and OLR treating residual waters of swine farming. Engenharia Agrícola, v. 33 , n. 2, p. 367-378, 2013

VANDERZANT, C.; SPLITTSTOESSER, D. F. Compendium of methods for microbiological examination for foods. 3 ed. Washington: American Public Health Association, p. 325-367, 1992.

VIANCELLI, A.; KUNZ, A.; STEINMMETZ, R. L. R.; KICH, J. D.; SOUZA, C. K.; CANAL, C. W.; COLDEBELLA, A.; ESTEVES, P. A.; BARARDI, C. R. M. Performance of two swine manure treatment systems on chemical composition and on the reduction of pathogens. Chemosphere, v. 90, n. 4, p. 1539-1544, 2013.

VIVAN, M.; KUNZ, A.; STOLBERG, J.; PERDOMO, C.; TECHIO, V. H. Eficiência da interação biodigestor e lagoas de estabilização na remoção de poluentes em dejetos de suínos. Revista Brasileira de Engenharia Agrícola e Ambiental, v. 14, n. 3, p. 320-325, 2010.

XAVIER, C. A. N; LUCAS JUNIOR, J. Parâmetros de dimensionamento para biodigestores batelada operados com dejetos de vacas leiteiras com e sem uso de inóculo. Engenharia Agrícola, v. 30 , n. 2, p. 212-223, 2010

XIE, S. LAWLOR, P. G.; FROST, J. P.; HU, Z.; ZHAN, $X$. Effect of pig manure to grass silage ratio 
REA - Revista de estudos ambientais (Online)

v.19, n. 1, p.6-17, jan./jun. 2017

on methane production in batch anaerobic codigestion of concentrated pig manure and grass silage. Bioresource Technology, v. 102, n. 10, p. 5728-5733, 2011.

ZAR J. H. 1999. Biostatistical analysis. 4. ed. New Jersey: Prentice-Hall, 1999.

ZHANG, D.; CHEN, Y.; ZHAO, Y.; ZHU, X. New sludge pretreatment method to improve methane production in waste activated sludge digestion.
Environmental science \& technology, v. 44, n. 12, p. 4802-4808, 2010.

\section{Acknowledgements}

To the National Council for Scientific and Technological Development (CNPq) for the financial support provided to the project. 